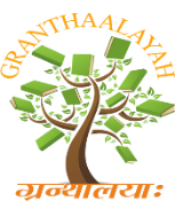

INTERNATIONAL JOURNAL OF RESEARCH GRANTHAALAYAH A knowledge Repository

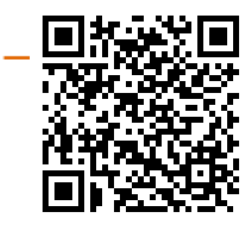

Science

\title{
AQUIFER TRANSMISSIVITY VALUES FROM VES FOR PARTS OF PORT HARCOURT, RIVERS STATE, NIGERIA
}

\author{
Eke P.O ${ }^{* 1}$, Life-George $\mathrm{F}^{2}$ \\ ${ }^{* 1}$ Department of Physics, Ignatius Ajuru University of Education Port Harcourt, Nigeria \\ ${ }^{2}$ Department of Mathematics, Ignatius Ajuru University of Education Port Harcourt, Nigeria
}

\begin{abstract}
This paper presents aquifer transmissivity values obtained from vertical electrical sounding method from some locations in Port Harcourt Local Government Area of Rivers State. Twelve (12) stations were occupied using the Schlumberger electrode configuration with maximum electrode spacing of $400 \mathrm{~m}$. The data were interpreted using IPI2WIN software version 3.0.1 (2003).The results reveal four layer strata with transmissivity ( $\mathrm{Tr}$ ) values of between 145.53 and $18264.42 \mathrm{~m} 2 /$ day with average value of $7252.23 \mathrm{~m} 2 /$ day. These indicate high aquifer transmissivity values for the study area with high permeable and significant storability of the formations that enhances the migration and circulation of ground water within the region. The results indicate that the southern part of the study area is the most prolific in terms of groundwater exploitation and thus the most promising in sitting productive boreholes.
\end{abstract}

Keywords: Apparent Resistivity; Aquifer Characteristics; Geoelectric Section; Schlumberger Array; Transmissivity; Vertical Electrical Sounding.

Cite This Article: Eke P.O, and Life-George F. (2018). "AQUIFER TRANSMISSIVITY VALUES FROM VES FOR PARTS OF PORT HARCOURT, RIVERS STATE, NIGERIA.” International Journal of Research - Granthaalayah, 6(4), 291-300. https://doi.org/10.29121/granthaalayah.v6.i4.2018.1664.

\section{Introduction}

The sitting of boreholes in Rivers State has not been effectively monitored by the Rivers State Water Management Board (RSWMB). This has affected the management and supply of water within the state as most inhabitants in the state site boreholes for water without advice from the Board or other related agencies. Available records in the Water Board show a number of isolated pre-drilling geophysical survey data for sitting boreholes in some parts of the state. However, majority of the boreholes drilled in the state are done without consultation of the Board for these information or proper geophysical investigation of the aquifer characteristics of the area. This practice is common in the state capital Port Harcourt with its increasing population. The consequences of this unplanned sitting of boreholes in future will be environmental problems of declining water table, land subsidence, salt-water intrusion and deteriorated quality by pollutions 
from the over exploited groundwater resources [1]. It is therefore important that a detailed geophysical and hydrogeological appraisal of Port Harcourt city be carried out to determine the aquifer parameters of formations as a guide to sitting boreholes and to avoid the above problems in future. As a contribution to knowledge of aquifer characteristics of the formations within Port Harcourt environs, vertical electrical sounding (VES) data from some parts of the city have been interpreted to obtain the transmissivity values and hence infer the ground water productivity of the region.

The study area (Fig. 1) is the northern part of Port Harcourt city $\left(4.8156^{\mathrm{O}} \mathrm{N}, 7.0498^{\mathrm{O}} \mathrm{E}\right)$ in Rivers State that lies in the southern part of the Niger Delta Basin of Nigeria. The structure and geology of the region has been fully documented by several authors $[2 ; 3 ; 4]$. Three major Formations have been identified in this region. These are the Akata Formation overlain by the Agbada Formation and the Benin Formation which is the top most Formation. The Benin Formation is characterized by high sandstones percentage of about $70 \%$ and varies in depth from the surface of the Earth to about 2,100 $\mathrm{m}$ below it [5]. This Formation is where most of the aquifers lie.

Port Harcourt city lies along the Bonny River and is drained by smaller creeks. It has a total land mass area of about $360 \mathrm{~km}^{2}$ and water mass area of $9 \mathrm{~km}^{2}$ with an average monthly rainfall of about $192 \mathrm{~mm}$ falling on an average of 3 days per week [6].

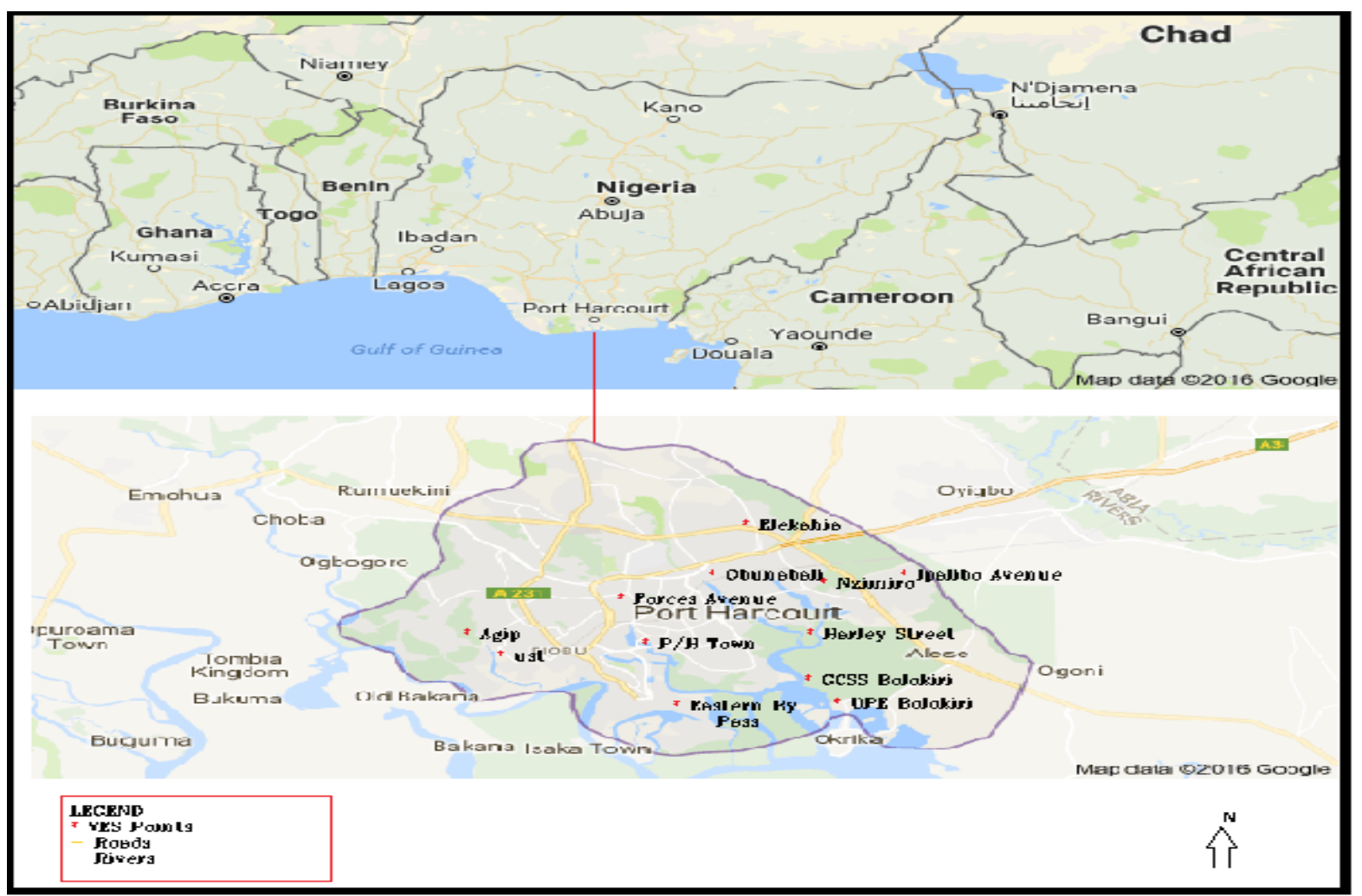

Figure1: Map of Study Area Showing VES Points (modified from [7], maps of Nigeria and Port Harcourt)

Previous studies in the region and its environs on aquifer characteristics and hydrological studies include the works of Ehirim and Nwankwo [8] and Ekine and Osobonye [9]. 


\section{Materials and Methods}

The data for this study was from the Rivers State Water Management Board VES survey of Port Harcourt city. The Schlumberger array method of electrodes spacing was used in the survey because of its advantage in terms of time effectiveness, field work arrangement, and good signal to noise ratio, excellent vertical resolution, poor lateral resolution, and high EM coupling. A maximum electrode spacing of $400 \mathrm{~m}$ was used. The geometric factor, $\mathrm{G}$, and apparent resistivity, $\rho_{a}$, for the Schlumberger array obtained from the [10] equation is

$$
\begin{aligned}
& G=\pi\left(\frac{s^{2}}{a}-\frac{a}{4}\right) \\
& \rho_{a}=\pi R\left[\frac{s^{2}}{a}-\frac{a}{4}\right]
\end{aligned}
$$

Where:

$$
\begin{aligned}
& R=\text { resistance in ohm (read from the Terameter }) \\
& \qquad \begin{array}{l}
s=A B / 2=\text { half current electrode spacing }(\mathrm{m}) \\
a=M N=\text { potential electrode spacing }(\mathrm{m})
\end{array}
\end{aligned}
$$

The apparent resistivity values computed were plotted against half of the current electrode spacing (AB /2) on a log-log graph scale. The sounding curves obtained were subjected to conventional partial curve matching using master curves [11] to obtain the initial model parameters of the resistivities and thickness of the various geoelectric layers. The apparent resistivity data $\rho_{\mathrm{a}}(\Omega \mathrm{m})$ from field measurements were inverted using IPI2WIN resistivity sounding interpretation software version 3.0 (2003) to obtain the true resistivity and depths of the subsurface formations.

Zohdy (1989) shows that for a confined aquifer of thickness, $b$, hydraulic conductivity, $K$, transverse resistance, $R_{T}$, and longitudinal conductance, $L_{C}$, the transmissivity, $T_{r}$, is

$$
T_{r}=K b=K \frac{R_{T}}{\rho}=K \sigma R_{T} \quad=K L_{C} \rho=K \frac{L_{C}}{\sigma}
$$

This represents the rate at which water of a given density and viscosity is transmitted through a unit width of aquifer or aquitard under a unit hydraulic gradient with dimensions of $L^{2} T^{-1}$. For an unconfined aquifer, the transmissivity is not as well defined as in a confined aquifer, but Equation 3 can be applied with $b$ now representing the saturated thickness of the aquifer or the height of the water table above the top of a lower aquitard boundary [10]. The transmissivity will, therefore, vary if there are large seasonal fluctuations in the elevation of the water table or if the saturated thickness of the aquifer shows lateral variation as a result of an irregular lower aquitard boundary or differences between recharge and discharge areas in the same aquifer. Based on the equation above, the quantities $(K \sigma)$ and $(k / \sigma)$ are assumed to be fairly constant within the watershed. Thus knowing the values of $K$ from existing boreholes and the conductivity, the inverse of resistivity from the sounding interpretation around the borehole, the transmitivity and its variation from place to place can be estimated using the Dar-zarrock parameter determined for each aquifer on the condition that $\sigma$ or $1 / \rho$ must be equivalent to any of the sets $K \sigma T$ or $K L_{C}$ or $K L_{C} / \rho$ to be used. 
Since the transverse resistance is the total resistance through a geoelectric section perpendicular to the bedding plane and $\rho$ is the resistivity, for a geoelectric section (an aquifer) of thickness, $h$, the transverse resistance $R_{T}$ is

$$
R_{T}=\rho h(\Omega m)
$$

\section{Results and Discussions}

Figures 2,3,4,5, 6 and 7 shows the VES curves from a plot of the apparent resistivity against current electrode spacing using IPI2WIN version 3.0 (2003) software for the locations of Elekahia, UST campus, Port Harcourt Town, Harley street, Eastern By Pass and UPE Bolokiri in the study area.

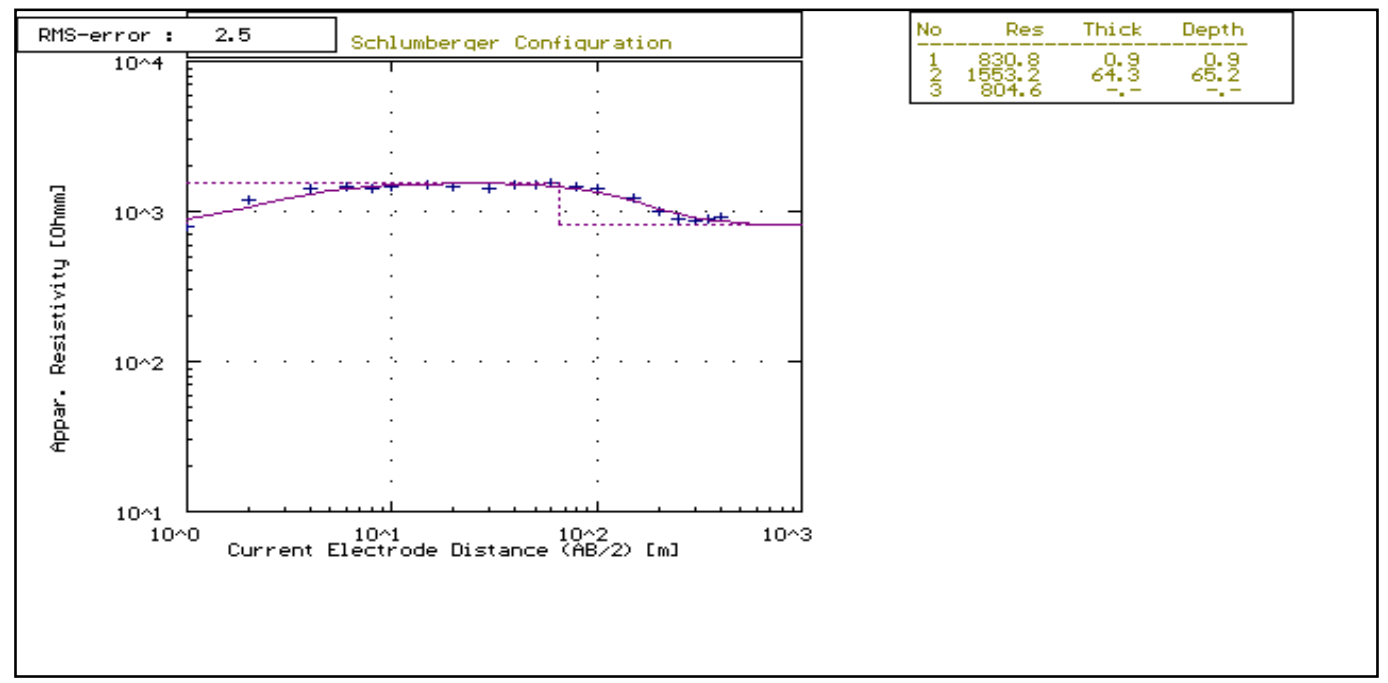

Figure 2: VES curve for Elekahia location

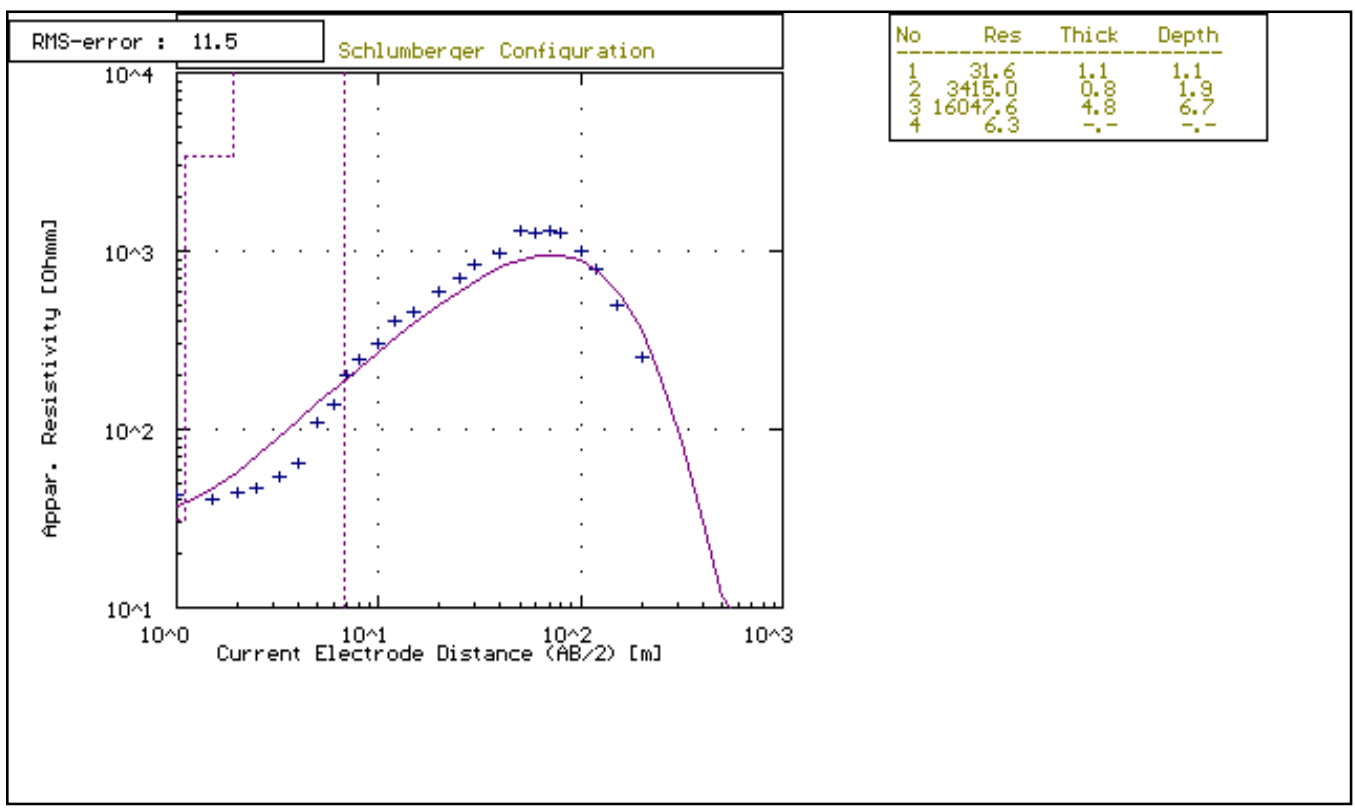

Figure 3: VES curve for UST campus location 


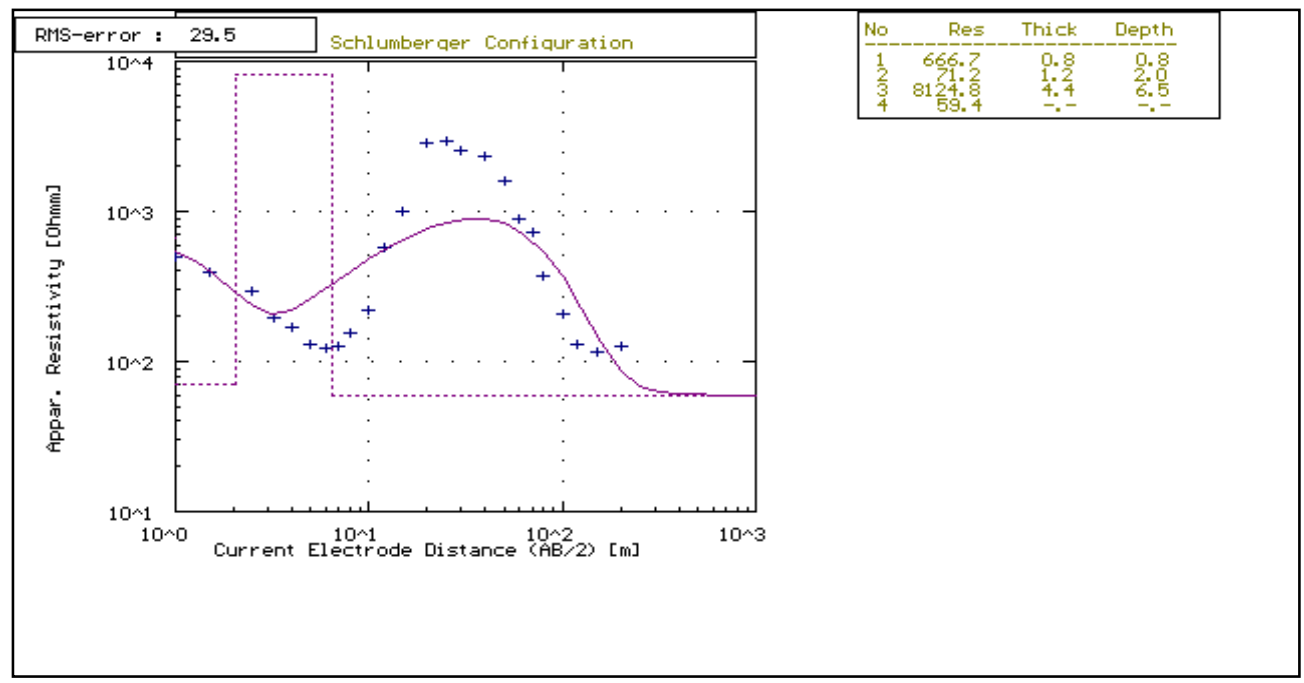

Figure 4: VES curve for Port Harcourt Town

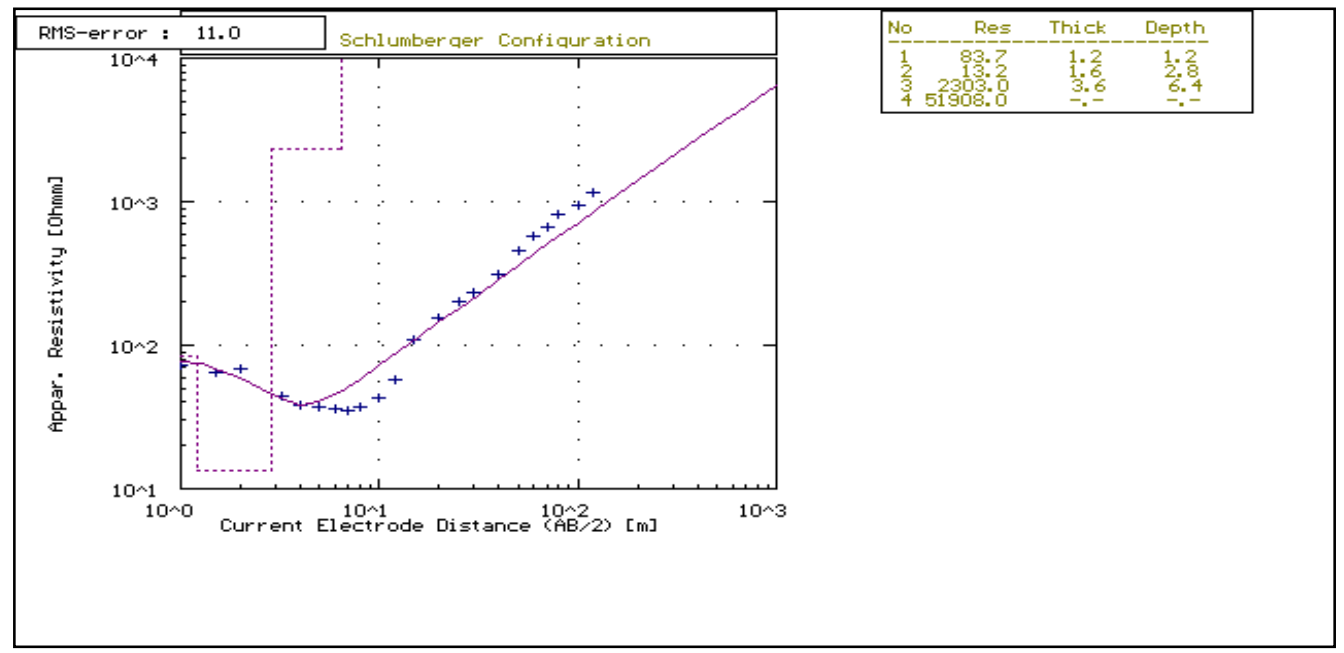

Figure 5: VES curve for Harley street location

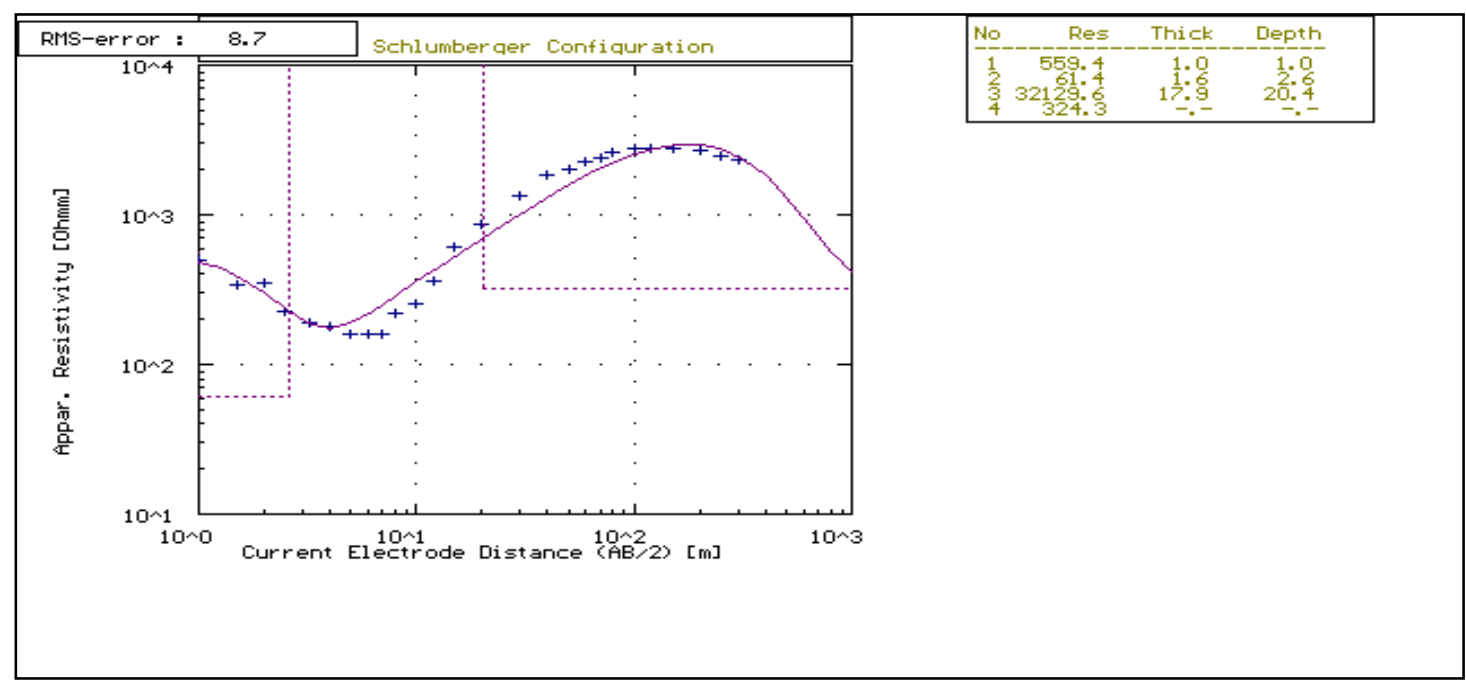

Figure 6: VES curve for LNG Eastern by Pass location 


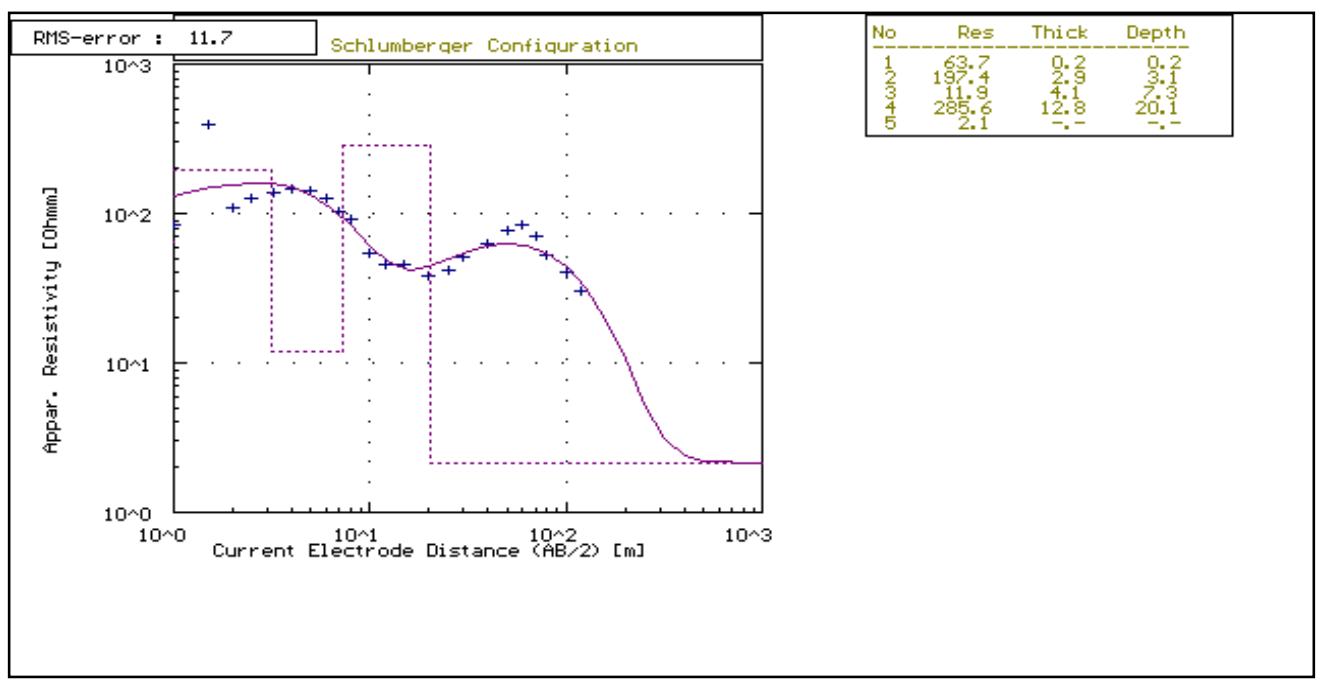

Figure 7: VES curve for UPE Bolokiri location

Table 1 is a summary of the curve results for all the locations showing the aquifer resistivity, number of layers, and depth to layers and layer thickness, while Table 2 is a summary of computed aquifer hydraulic parameters of the study area.

Table 1: Summary of VES curve results for all the locations

\begin{tabular}{|l|l|l|l|l|l|l|}
\hline S/N & Location & \multicolumn{1}{l}{$\begin{array}{l}\text { No } \\
\text { layers }\end{array}$} & $\begin{array}{l}\text { of } \\
\text { Aquifer Resistivity } \\
\text { (m) }\end{array}$ & $\begin{array}{l}\text { Depth } \\
(\mathbf{m})\end{array}$ & \multicolumn{1}{l}{$\begin{array}{l}\text { Thickness } \\
(\mathbf{m})\end{array}$} \\
\hline $\mathbf{1}$ & UPE Bolokiri & 1 & 63.7 & 0.2 & 0.2 \\
& & 2 & 197.4 & 3.1 & 2.9 \\
& & 3 & 11.9 & 7.3 & 4.1 \\
& & 4 & 285.6 & 20.1 & 12.8 \\
\hline $\mathbf{2}$ & GCSS Bolokiri & 1 & 2.1 & - & - \\
& & 2 & 121.0 & 0.5 & 0.5 \\
& & 3 & 752.0 & 1.6 & 1.1 \\
& & 4 & 19638.9 & 21.3 & 19.6 \\
\hline $\mathbf{3}$ & Port Harcourt & 1 & 666.7 & - & - \\
& Town & 2 & 71.2 & 0.8 & 0.8 \\
& & 3 & 8124.8 & 2.0 & 1.2 \\
& & 4 & 59.4 & 6.5 & 4.4 \\
\hline $\mathbf{4}$ & Eastern By Pass & 1 & 559.4 & - & - \\
& & 2 & 61.4 & 1.0 & 1.0 \\
& & 3 & 32129.6 & 2.6 & 1.6 \\
& & 4 & 324.3 & 20.4 & 17.9 \\
\hline $\mathbf{5}$ & Harley Street & 1 & 83.7 & 39.1 & 18.7 \\
& & 2 & 13.2 & 1.2 & 1.2 \\
& & 3 & 2303.0 & 2.8 & 1.6 \\
& & 4 & 51908.0 & 6.4 & 3.6 \\
\hline $\mathbf{6}$ & Forces Avenue & 1 & 152.7 & - & - \\
\hline
\end{tabular}




\begin{tabular}{|l|l|l|l|l|l|}
\hline & & 3 & 462.6 & 59.7 & 14.7 \\
\hline $\mathbf{7}$ & Nzimiro Avenue & 4 & 56.6 & - & - \\
& & 2150.5 & 1.6 & 1.6 \\
& & 3 & 965.4 & 16.0 & 14.4 \\
& & 4458.0 & 46.7 & 30.7 \\
\hline $\mathbf{8}$ & UST & 1 & 31.6 & 73.4 & 26.4 \\
& & 2 & 3415.0 & 1.1 & 1.1 \\
& & 3 & 16047.6 & 1.9 & 0.8 \\
& & 4 & 6.3 & 6.7 & 4.8 \\
\hline $\mathbf{9}$ & UST by Agip & 1 & 105.7 & 29.8 & 23.1 \\
& & 2 & 3.8 & 6.1 & 6.1 \\
& & 3 & 138.6 & 148.9 & 142.8 \\
\hline $\mathbf{1 0}$ & Ipalibo Avenue & 1 & 69.8 & 167.6 & 18.7 \\
& & 2 & 258.7 & 2.3 & 2.3 \\
& & 3 & 19.5 & 7.6 & 5.3 \\
& & 4 & 374.8 & 18.0 & 10.5 \\
\hline $\mathbf{1 1}$ & Ogbunabali & 1 & 2171.8 & 33.7 & 15.7 \\
& & 2 & 550.3 & 2.8 & 2.8 \\
& & 3 & 9802.8 & 10.6 & 7.8 \\
& & 4 & 172.6 & 24.0 & 13.4 \\
& & 5 & 18690.8 & 72.2 & 48.2 \\
\hline $\mathbf{1 2}$ & Elekahia & 1 & 830.8 & - & - \\
& & 2 & 1553.2 & 0.9 & 0.9 \\
& & 3 & 804.6 & 65.2 & 64.3 \\
\hline
\end{tabular}

Table 2: Summary of Computed Aquifer Hydraulic Parameters for the Study Area

\begin{tabular}{|c|c|c|c|c|c|}
\hline Location & $\begin{array}{l}\text { Aquifer } \\
\text { Resistivity } \\
\rho_{a}(\Omega \mathrm{m})\end{array}$ & $\begin{array}{l}\text { Aquifer } \\
\text { Depth } \\
d(\mathrm{~m})\end{array}$ & $\begin{array}{l}\text { Aquifer } \\
\text { Thickness } \\
h(\mathbf{m})\end{array}$ & $\begin{array}{l}\text { Transverse } \\
\text { Resistance } \\
R_{T}=\rho_{a} h \\
\left(\Omega^{2}\right)\end{array}$ & $\begin{array}{l}\text { Aquifer } \\
\text { Transmissivity } \\
T_{r}=R_{T}=\rho_{a} h \\
\left(\mathbf{m}^{2} / \text { day }\right)\end{array}$ \\
\hline UPE Bolokiri & 285.6 & 20.1 & 4.1 & 1170.96 & 1170.96 \\
\hline GGSC Bolokiri & 75.1 & 21.3 & 19.6 & 1471.96 & 1471.96 \\
\hline Port Harcourt Town & 59.4 & 43.6 & 37.1 & 2203.74 & 2203.74 \\
\hline $\begin{array}{l}\text { Eastern By } \\
\text { Pass }\end{array}$ & 324.3 & 39.1 & 18.7 & 6064.41 & 6064.41 \\
\hline Harley Street & 2303.0 & 6.4 & 3.6 & 8290.80 & 8290.80 \\
\hline Forces Avenue & 462.6 & 59.7 & 14.7 & 6800.22 & 6800.22 \\
\hline Nzimiro Street & 978.0 & 73.4 & 26.4 & 25819.20 & 25819.20 \\
\hline UST & 6.3 & 29.8 & 23.1 & 145.53 & 145.53 \\
\hline UST By AGIP & 138.6 & 167.6 & 18.7 & 2591.82 & 2591.82 \\
\hline Ipalibo Avenue & 374.8 & 33.7 & 15.7 & 5884.36 & 5884.36 \\
\hline Ogbunabali & 172.6 & 72.2 & 48.2 & 8319.32 & 8319.32 \\
\hline Elekahia & 804.6 & 87.9 & 22.7 & 18264.42 & 18264.42 \\
\hline
\end{tabular}


Figures 8 and 9 are contour maps of depth to water table and hydraulic conductivity of the study area.

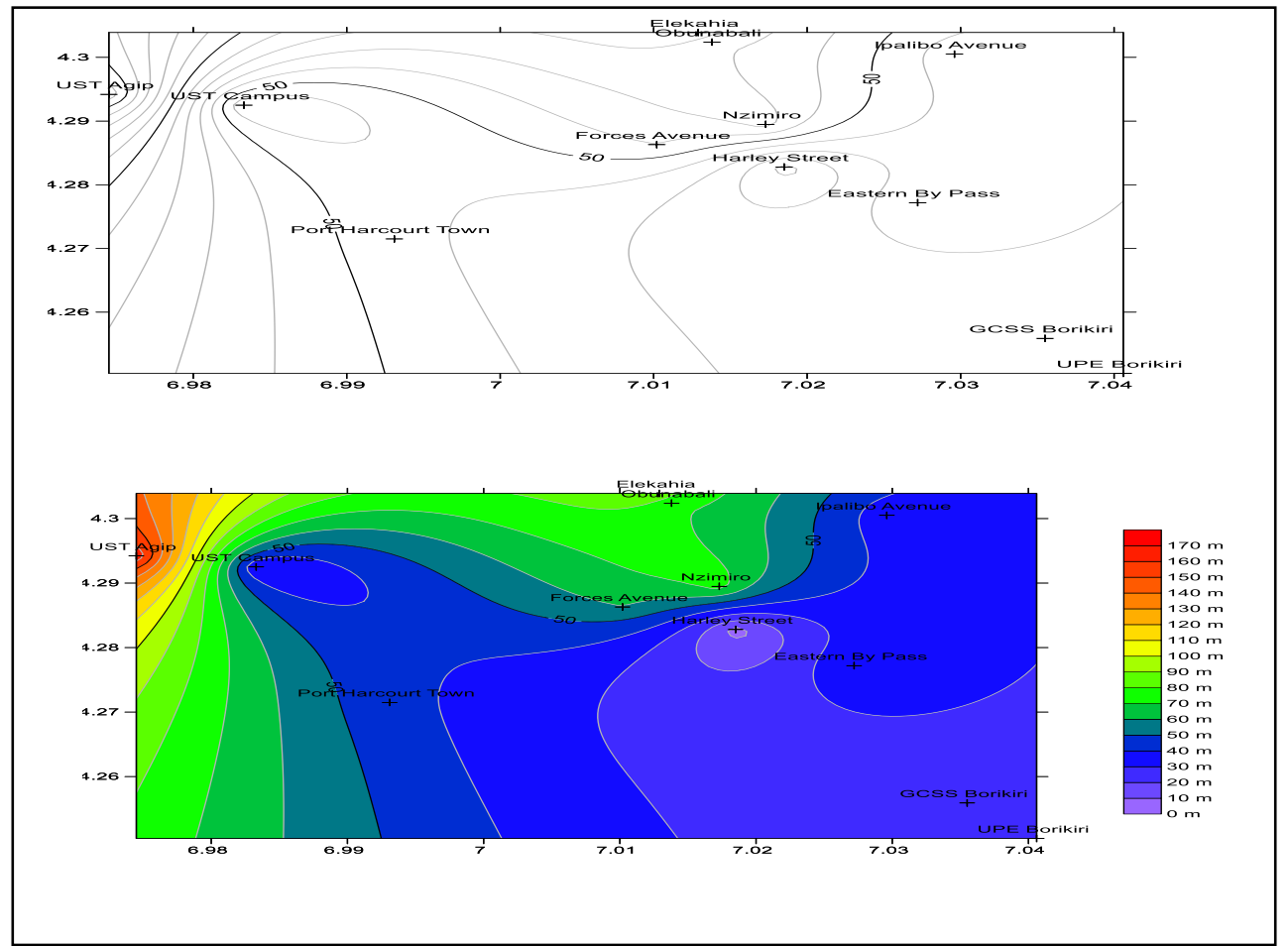

Figure 8: Contour map of depth to water table

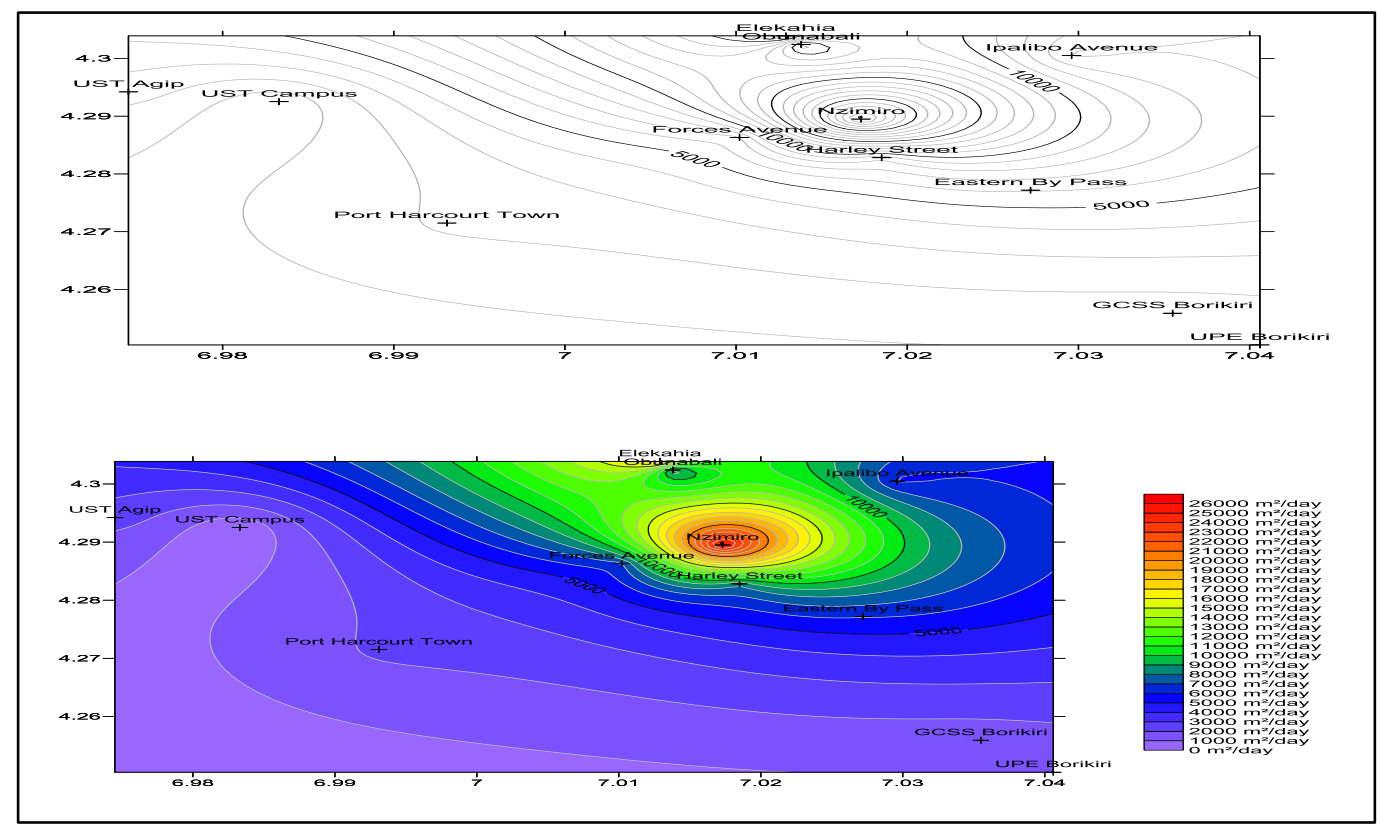

Figure 9: Contour map of transmissivity of study area

The aquifer and Dar-Zarouk parameters for all the locations are presented in Tables I and 2 respectively. The main aquiferous zones occur between the 3 th and 4 th geoelectric layers with a 
resistivity range of 6.3 to $2303 \Omega \mathrm{m}$, depths varying from $6.4 \mathrm{~m}$ to $167.6 \mathrm{~m}$, and layer thickness varying from $3.6 \mathrm{~m}$ to $48.2 \mathrm{~m}$.

The contour map of depth to water table exhibits variance in aquifer depth distribution as shown in Fig.8. The depth to water table decreases along the NW-SE axis of the study area, the northwestern region appearing to have deep aquifers (red colour) with UST in Agip area having the highest depth value of $167.6 \mathrm{~m}$ while the southeastern region have shallow aquifers (purple colour) with GSS Borikiri and UPE Borikiri areas having the lowest depth value of $20.5 \mathrm{~m}$.

The results show that the depth to water table in the UST area is deep compared to the surroundings of the study area. This implies that the areas within the UST axes might be good for sitting boreholes that will produce potable water if the thickness and hydraulic conductivity of the area is adequate.

The transmissivity $T_{r}$ and the transverse resistance $R_{T}$ of the aquiferous zones from the results vary from $145.53 \mathrm{~m}^{2} /$ day to $25819.20 \mathrm{~m}^{2} /$ day. These values correspond to zones where the thicknesses and resistivities of the aquifer are large. The high transmissivities suggest that the aquifer materials are highly permeable to fluid movement within the aquifer with good groundwater potentials. The knowledge of $T_{r}$ distribution as shown in the Fig.9 is a fundamental source of information for establishing a hydrogeological model.

The northern flank of the study area displays areas of high transmissivity with areas around Nzimiro (red colour) having the highest transmissivity value of $25819.20 \mathrm{~m}^{2} /$ day followed by areas around Elekahia (orange colour) with transmissivity value of $18264.42 \mathrm{~m}^{2} /$ day. Areas around UST compound (purple colour) display low transmissivity value of $45.53 \mathrm{~m}^{2} /$ day. Every other part within the study area have transmissivity value greater than $400 \mathrm{~m}^{2} /$ day suggesting that a greater part within the study area are of considerable permeability to fluid movement within the aquifer with appreciable good groundwater potentials [8].

\section{Conclusions and Recommendations}

The calculated aquifer parameters are within the range of observed aquifer parameters as obtained from the works of Ehirim and Nwankwo [8] and, Ekine and Osobonye [9]; carried out within the same Benin Formation of the Niger delta. The high values of transmissivity recorded in most parts of the study area agree with the geology of the Benin Formation consisting mainly of fine-mediumcoarse sands. Also the southern part of the study area is the most prolific in terms of groundwater yield based on the transmissivity values and therefore the most promising in sitting productive boreholes. It is recommended that this region should be the major area for water project to sustain the hydrological balance of the city and to avoid any environmental problem that may arise from indiscriminate sitting of boreholes in future.

\section{Acknowledgements}

The authors thank the management of Rivers State Water Management Board for the data used in this work. 


\section{References}

[1] Esteller, M.V. and Daiz-Delgado, C. Environmental Effects of Aquifer Overexploitation: A Case Study in the Highlands of Mexico, Environ. Man., 29(2), 2002; 266-278.

[2] Merki, P.J., 1972. Structural Geology of the Cenozoic Niger Delta, 1st Conference African Geology, Ibadan, 1970, Ibadan, Nigeria: Ibadan University Press, 1972, 635-646.

[3] Obaje, N.G. (2009).Geology and mineral resources of Nigeria. Springer-Verlag Berlin Heidelberg. 2009, 109-113.

[4] Eke P.O. and Okeke, F.N. Identification of Hydrocarbon Regions in Southern Niger Delta Basin of Nigeria from Potential Field Data. International Journal of Science and Technology Research, 5(11), 2016, 96-99.

[5] Evamy, B.D., Haremboure, J., Kamerling, P., Knaap, W.A., Molloy, F.A. and Rowlands, P.H. Hydrocarbon habitat of tertiary Niger Delta. AAPG Bull, 62(1), 1978, 1-39.

[6] Niger Delta Regional Development Master Plan, NDRDMP. Niger Delta Region and People: NDRDMP report. http://www.nddc.gov.ng/NDRDMP\%20chapter201., 2000, 49-99.

[7] Google Maps 2016, Map of Nigeria, www.google.com/maps/nigeria.html- retrieved 20/03/17.

[8] Ehirim, C.N. and Nwankwo, C.N. Evaluation of Aquifer Characteristics and Groundwater Quality Using Geoelectric Method in Choba, Port Harcourt. Archives of Applied Science Research, 2(2), 2010, 396-403.

[9] Ekine, A.S. and Osobonye, G.T. Surface Geoelectric Sounding for the Determination of Aquifer Characteristics in Parts of Bonny Local Government Area of Rivers State. Nigerian Journal of Physics, 85, 1996, 93-97.

[10] Zohdy, A.A.R. A New Method for the Automatic Interpretation of Schlumberger and Wenner sounding curves, Geophysics, 54, 1989, 245-253.

[11] Orellena, E. and Mooney, H.M. (1966). Master Tables and Curves for Vertical Electrical Sounding over Layered Structures. Intersci., Madrid, 1996, 23-35.

*Corresponding author.

E-mail address: ekepetero2@yahoo.com 